\title{
Socioeconomic Inequalities in Birth and Pregnancy Outcomes in the Czech Republic between 1990 and 2007: An Exploration of Trends*
}

\author{
MARTINA ŠTÍPKOVÁ** \\ University of West Bohemia, Pilsen, and Charles University, Prague \\ MARTIN KREIDL** \\ Masaryk University, Brno
}

\begin{abstract}
This article explores the impact of the post-socialist transformation of Czech society on the health of newborns from different socioeconomic groups. The authors used six different measures of child health-various constructs based on birth weight, length of gestation, and vitality-as dependent variables and the mother's educational attainment as the key predictor. They used birth certificate data on all singleton births in 1990, 1992, 1994, 1996, 1998, 2000, 2002, 2004 and 2007 ( $N=912591$ ). They estimated a series of random-intercept multi-level models and report the observed trends in health inequality by maternal education. The analysis consistently and persistently showed large gaps in health between children born to mothers with elementary education on the one hand and all other children on the other hand. While the trends are not entirely congruent across all measures of child health, the authors found more evidence of growing inequality than of declining or stable inequality. Inequality grew most in the 1990s and then stabilised or even declined. They offer two tentative explanations for observed growth in inequality: the selective adjustment hypothesis and the selective childlessness hypothesis.
\end{abstract}

Keywords: health inequality, child health, birth weight, post-socialist transformation, Czech Republic

Sociologický časopis/Czech Sociological Review, 2011, Vol. 47, No. 3: 531-564

\footnotetext{
* This research received financial support from the Grant Agency of Charles University in Prague (grant number 40010), from the institutional research support of the Faculty of Philosophy and Arts of the University of West Bohemia, and from the large-scale research scheme of the Ministry of Education, Youth, and Sports (reg. no. MSM0021622408).

** Direct all correspondence to: Martina Štípková, Department of Sociology, University of West Bohemia, Univerzitní 8, 30614 Plzeň, Czech Republic, e-mail: marsti@kss.zcu.cz; Martin Kreidl, Faculty of Social Studies, Masaryk University, Joštova 10, 60200 Brno, Czech Republic, e-mail: kreidlm@fss.muni.cz.
}

(C) Sociologický ústav AV ČR, v.v.i., Praha 2011 


\section{Introduction: socioeconomic transformation and population health}

Many former socialist countries witnessed a pronounced and prolonged deterioration of population health after 1989. While many scholars expected that population health would improve once the oppressive and dysfunctional political system and inefficient command economy were dismantled, a mortality crisis took place instead. Russia is the most often cited example of this. According to available data, life expectancy at birth had been declining slowly since the second half of the 1980s in Russia and then fell from 64 years to 58 in men and from 74 to 71 in women between 1991 and 1994 [Meslé 2004]. The mortality rate and life expectancy were worse for men in 2007 than at the beginning of the 1990s [Federal State Statistics Service 2009].

The post-socialist development of population health-in Russia and elsewhere-is often attributed to the accompanying social and economic changes that occurred during this period. Socioeconomic status, work conditions, marital status, the character of a person's social network, and even the character of the community that people live in are often mentioned as determinants of an individual's health (for details, see, e.g., Bartley, Blane and Smith [1998]; Blaxter [1991]; Cockerham [2007]; Grigoriev et al. [2010]; Marmot [2004]). Since social, economic, geographic, and demographic structures changed dramatically during the post-socialist period, these transformations were frequently seen as the culprits behind the worsening of population health. For instance, Adeyi et al. [1997] and Grigoriev et al. [2010] see the possible causes of this deterioration in health as lying in the decrease in real incomes, greater exposure to stress (connected, for instance, to job insecurity, unemployment, growing income inequality, weakening family stability), and more widespread stress-related behaviour (such as an upsurge in alcohol consumption), poor regulation of environmental risks, and deteriorating health care (see also Chen, Wittgenstein and McKeon [1996]; Cockerham [1997]; Marmot and Bobak [2000]; Stuckler, King and McKee [2009]).

This article focuses on the health situation in the post-socialist Czech Republic, which witnessed a rapid and rather unprecedented improvement of many indicators of population health in the 1990s [Blažek and Dzúrová 2000]. If we look at infant health in the transition period, which is the main focus of this article, we find that the gross infant mortality rate increased from 10.0 to 10.8 between 1989 and 1990 and then experienced a fourfold decrease. Its 2008 level (2.8 deaths per 1000 live births) ranks the Czech Republic among the ten countries with the lowest infant mortality in the world [United Nations 2010; see also Koupilová et al. 2000].

Yet, another important indicator of child health, mean birth weight, exhibited less positive development in the Czech Republic. While newborn children weighed on average 3308 grams in 1989, mean birth weight dropped to 3276 grams in 1991. Later, mean birth weight improved continuously until 1999, when it peaked at 3339 grams, only to fall again to 3293 grams by 2008, i.e. below 
the level it was at in 1989 [Czech Statistical Office 2008, 2009]! Similarly the proportion of preterm deliveries-i.e. births before the 38th week of pregnancy-remained stable until 2002, ranging between $7.7 \%$ and $8.8 \%$, and then increased to $10.5 \%$ in 2007 (see Table 1). ${ }^{1}$

It is possible that different socioeconomic groups experienced different health trends. Before we proceed to our analysis of these disparities, we will briefly review what is known about stratification of health in general and infant health in particular during the post-socialist period and we also describe possible sources of the new socioeconomic patterns of infant health in the Czech Republic.

\section{Health inequality in the post-socialist period}

The post-socialist health crisis (and the subsequent health improvements) did not affect all groups of adults in the same fashion. The rise in mortality occurred mostly among the population of productive age (20-59 years) and impacted men more than women, further widening the gender gap that existed before the regime change [Cornia and Paniccià 2000: 13]. The socioeconomic health gap that existed in socialist countries despite their egalitarian ideology [Shkolnikov et al. 1998; Sobotík and Rychtaříková 1992] also grew after 1989 [Shkolnikov et al. 1998], as the negative consequences of social transformation had a disproportionate impact on less educated people.

In addition, disparities in mortality by marital status, migrant status, and ethnic origin increased in the post-socialist states, negatively impacting lone-parent families, illegal migrants, and ethnic minorities [Cornia and Paniccià 2000: 16-28; Pikhart, Drbohlav and Dzúrová 2010]. People in the Czech Republic witnessed the same changes as individuals in other transforming societies. People of productive age and young families were those most strongly impacted [Blažek and Dzúrová 2000].

As some pregnancy and birth indicators in the Czech Republic improved while others worsened (see above), it is possible that different social groups followed different paths of development and that some were thus left behind while others saw a disproportionately positive improvement in their situation. Interestingly, however, in the past two decades there has been little research conducted in post-socialist societies (including the Czech Republic) on socioeconomic

\footnotetext{
1 After 1989 there was a substantial increase in the share of newborns with a low birth weight, which is another frequently employed indicator of child health. In $2008,7.2 \%$ of newborns had a low birth weight compared to 5.5\% in 1990 [Czech Statistical Office 2008, 2009]. The rising number of multiple births, which is the result of the increased use of assisted reproduction techniques in recent years, explains this trend. The share of multiple births among all births grew from $0.9 \%$ to $2.0 \%$ between 1990 and 2008 [Czech Statistical Office 2008, 2009]. The share of newborns with a low birth weight has remained constant at $5 \%$ among singleton births (see Table 1 ).
} 


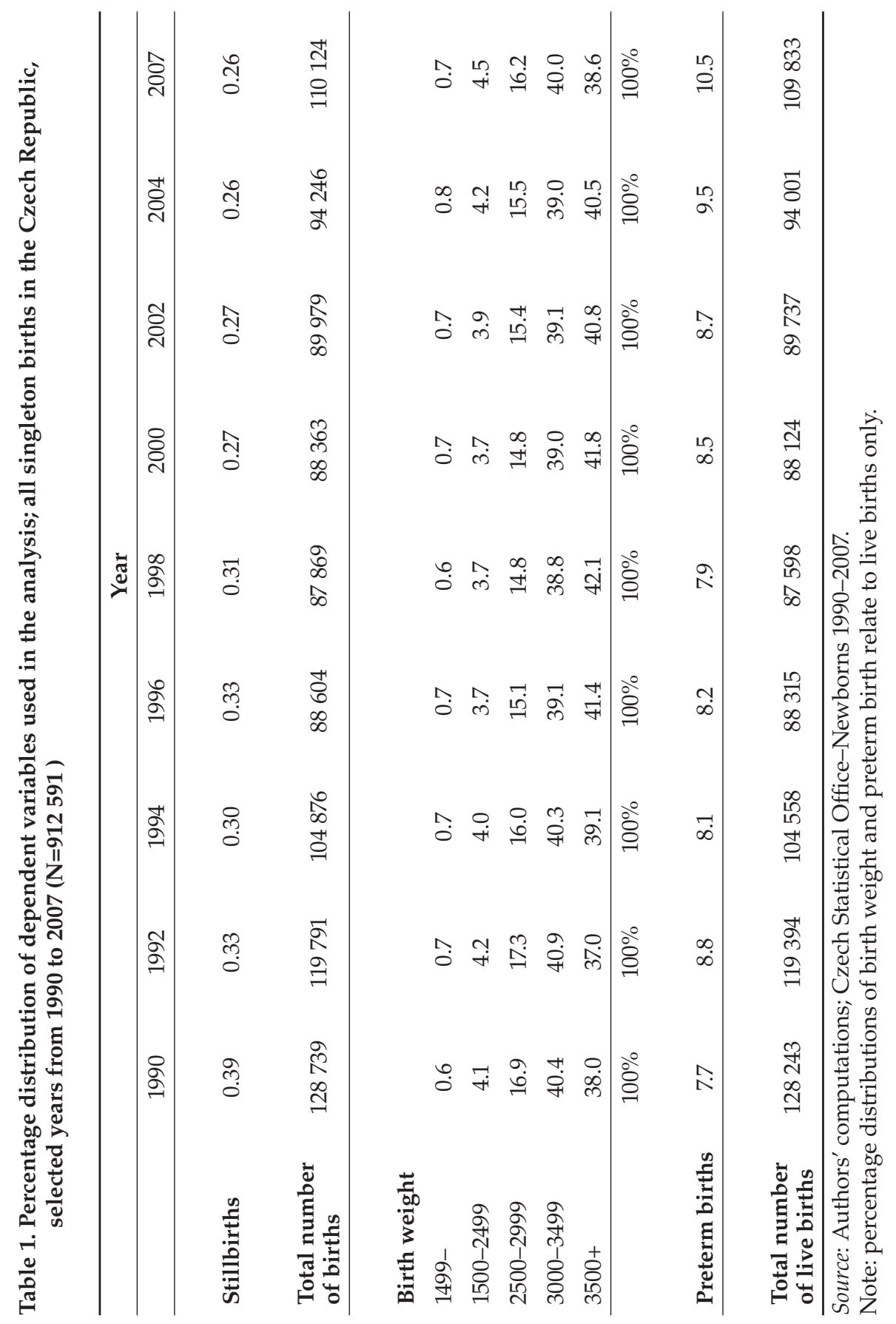


inequality in birth and pregnancy outcomes. Carlson, Hoem and Rychtaříková [1999], using data from the Czech Birth Register, showed that the higher the education of the mother, the lower the risk of foetal loss (i.e. abortion or stillbirth). Rychtař́ková and Demko [2001] found infant mortality to be highly stratified by maternal education in both the socialist and post-socialist periods. Bobák, Pikhart and Koupilová [2000] investigated the stratification of infant death from external causes and showed that infants and children of better educated mothers faced a lower risk of dying in any form of accident. Social inequalities in infant health were also confirmed in other post-socialist countries, such as the former East Germany and Estonia [Koupil et al. 2006; Raum et al. 2001]. According to the findings of Koupil et al. [2006], the gap in infant mortality by maternal education level in Estonia has even been widening.

To the best of our knowledge, there is only one published paper that has explicitly addressed the issue of the trend in the socioeconomic inequality of health among infants in the Czech Republic after 1989. Koupilová et al. [1998] inquired into the effect of maternal education on a birth weight, preterm delivery, and infant mortality in 1989-1991 and 1994-1996 using data from population registers on all live singleton births. These data showed an increase in the effect of the mother's education on birth weight (measured in grams) and on the odds of preterm delivery in OLS or logistic regression models.

Changes in the association between parental social status and the health of their children may have far-reaching stratification consequences. The socioeconomic status of parents, to a certain degree, translates into the health of their children [e.g. Gortmaker and Wise 1997; Kramer et al. 2000; Wise 2003], and child health then affects their adult socioeconomic status. A number of scholars have documented the consequences of poor birth and pregnancy outcomes for socioeconomic status later in life [e.g. Conley and Bennet 2002; Conley, Strully and Bennett 2003; Spencer and Law 2007]. Hence, growing socioeconomic inequality in child health may alter the entire process of intergenerational status inheritance. The social problem this change poses is twofold. The rise in child health inequalities represents a major, immediate threat to equity and a significant barrier to future intergenerational social mobility. Any such occurrence should be thoroughly monitored and analysed.

This paper investigates trends in socioeconomic inequality in the health of newborns in the Czech Republic between 1990 and 2007. While changes in the SES-health association are of intrinsic interest in any social context, the post-socialist Czech Republic is a particularly attractive case, since the country has experienced unprecedented improvements in population health (e.g. life expectancy at birth grew from 68 years to 74 in men and from 75 to 80 in women between 1990 and 2008 [Czech Statistical Office 2010]) and significant increases in economic and social inequality in many areas. Yet, our understanding of inequality in child health and its changes in this particular context is somewhat limited. 


\section{Changes in the social structure that may have affected birth and pregnancy outcomes}

Koupilová et al. [1998] offer a number of somewhat speculative explanations for the growing disparities in infant health that they observed in the Czech Republic in the first half of the 1990s. However, their main argument emphasises that growing inequality in birth outcomes truly reflects a divergence of living standards between less educated and better educated mothers. The authors maintain that declining real incomes and reductions in social security benefits have made the less educated comparatively more vulnerable to socioeconomic risks and have exacerbated existing differences. Koupilová et al. [1998] then imply that the social security reforms undertaken by the Czech government in the 1990s contributed significantly to the growing inequality in infant health. They also point to the increasingly socially stratified prevalence of smoking among pregnant women. The authors furthermore note the role in this played by the transformation of the Czech health-care system in the first half of the 1990s. Below, these and other possible sources of growing socioeconomic inequality in pregnancy and birth outcomes that escalated during the post-socialist transformation are reviewed.

Following the break-up of the socialist regime, the Czech Republic went through a period of economic decline that had a particularly negative impact on people with lower levels of education. Real incomes dropped in the early 1990s and inequality in the distribution of earnings and incomes increased remarkably after 1990 [Večerník 1999, 2001]. There was an increase in intra-generational occupational mobility and a massive exodus of people from the labour market. Employment rates shrank and unemployment-previously almost non-existentswelled [Večerník and Matěju 1999]. Employees experienced growing economic returns to education and increasing consistency between education, occupation, and earnings [e.g. Matějů and Kreidl 2001]. Socioeconomic risks became more stratified by education level and other statuses after 1989. These include the risk of unemployment and long-term unemployment [Frýdmanová et al. 1999; Hamplová and Kreidl 2006; Keune 2003], fear of unemployment [Mareš, Sirovátka and Vyhlídal 2003], and the risk of material deprivation [Večerník 1999]. Similarly, the odds of downward occupational mobility became more strongly stratified by education and gender [Katrňák et al. 2008]. In addition, poverty rates burgeoned and the nature of poverty itself changed [Mareš and Rabušic 1996]. There is a strong and growing association between the risk of poverty and an individual's human capital.

Social inequalities have also been shaped by social and family policy reforms. The reforms of the 1990s were directed towards less generous and incometested welfare benefits. Furthermore, state regulation of food prices and the negative taxation of many goods was discontinued in 1991 and was, for a limited period of time, substituted by a direct welfare payment ('vyrovnávací přispěvek' in Czech). This payment was universal until 1992 and then continued as a means- 
tested benefit until 1995. A new tax system was introduced in 1993 that established tax benefits for parents and redefined the child allowance ('prídavek na ditě' in Czech) to depend on the age of the children [Krebs 2005].

Family policy is of particular significance for this issue. While the socialist regime generously and universally supported newlyweds and parents with subsidised loans and allowances, these benefits were discontinued after 1989. Hiršl [2004] showed that the purchasing power of state support for families with children decreased dramatically after 1989. His 'model family', with two average incomes and two children, covered $53 \%$ of the standardised needs of children from state benefits (allowances, tax deductions) in 1989, compared to just 15\% in 2002. In addition, childcare centres-directly or indirectly subsidised by the statewere disappearing, which led to the marginalisation of parents in the job market [Hašková and Uhde 2009]. Conditions in the labour market have consequently become increasingly difficult for lone parents in particular. Numerous changes in family policy introduced in the 2000s expanded the choice-set available to parents, but frequent changes prevented family policy from offering stable and safe conditions for parents and their children [Kocourková 2008].

Health inequalities were perhaps also influenced by the transformation of the Czech health-care system in the first half of the 1990s. The reform assumed (and encouraged) a more active role for patients in seeking and utilising health care. It institutionalised the principle of the free choice of general practitioner (GP), as opposed to the previous system that bureaucratically assigned people to GPs based on their place of employment or residence. Moreover, the economics of health care changed too. The total share of GDP spent on the health-care system increased sharply in the first half of the 1990s from a level below 5\% to $7 \%$ (in 1995) and then stabilised at this level [Bryndová et al. 2009]. Private health-care centres were established, and all medical establishments, public as well as private, were forced to increase productivity with the newly introduced fee-for-service reimbursement system. This resulted in the widespread commercialisation of the health-care system's approach to its clients [see, e.g., Hasmanová Marhánková and Hrešanová 2008]. Overall, these changes emphasised individual agency and responsibility and may have made socioeconomic status a more salient factor influencing how and when (potential) patients seek out and use health-care services and a factor with an influence on the kind of services provided by health-care establishments and their personnel [Habicht et al. 2009]. These changes may have resulted in an increasing social gradient in pregnancy and birth outcomes [Koupilová et al. 1998].

To summarise, we believe that the growing overall exposure to risk and uncertainty, more stratified experience with various risk factors, increasing socioeconomic inequality, and the reform of institutions and policies may have increased the socioeconomic stratification of pregnancy and birth outcomes during the post-socialist transformation. Bobak, Pikhart and Koupilová [2000] argue that the adverse health consequences of the post-socialist transformation were 
caused by psychosocial factors that worked both directly and indirectly through health-related behaviour. They see the origins of psychosocial influences as lying in work conditions, harmful life events and everyday difficulties, social networks (marriage, friendship), job security, and the perceived amount of control a person has over his/her life. The trends in the social structure of Czech society described above suggest that these risks were unequally distributed.

\section{The main research focus and analytic strategy}

We argue that the post-socialist socioeconomic transformation may have affected the sources and patterns of social (dis)advantage in child health. Yet, it may also have transformed the mechanisms that link parental socioeconomic status to child health. It is rather difficult to clearly identify these causal pathways, since the complexity of the post-socialist social transformation is enormous and many changes occurred concurrently. Yet another serious complication in researching this issue is the lack of data capable of providing sufficiently detailed information about health status and a wide range of other potential explanatory and mediating variables.

Therefore, here we focus simply on describing trends in socioeconomic inequality in pregnancy and birth outcomes and explore the impact of the postsocialist transformation on the health of newborns in different socioeconomic groups. Our goal is to describe the development of socioeconomic disparities in the health of infants born in the Czech Republic since the beginning of the 1990s to the present day and to offer a (tentative) interpretation. We make no attempt to disentangle the various (potential) mediating mechanisms that might link socioeconomic status and health. Instead we make use of-conceptually and statistically speaking-'reduced-form models'. We regard these (simplifying) models as sufficient to assess whether the socioeconomic stratification of birth and pregnancy outcomes has changed and whether (and to what extent) this represents a public policy challenge.

Our analysis extends earlier research in this area [see, e.g., Koupilova et al. 1998] in three different ways. The exemplary paper by Koupilova et al. [1998], while rich in many respects, has three important limitations. First, it analysed only a short period in the early stages of the post-socialist period (until 1996), whereas we can map trends up to 2007, which may put us in a better position to identify clearly trends in inequality. Second, earlier research did not control for some relevant variables (e.g. administrative district). Consequently, it offered potentially biased estimates of the effect of the mother's education on child health. Third (and relatedly), previous analyses failed to consider and thus were unable to capitalise on the analytic options provided to researchers by the geographic clustering of data. Our research design acknowledges the clustered data structure and incorporates it directly into our statistical models via multilevel model- 
ling. As a result, our models are a more realistic representation of the actual data structure and can serve as a better building block for any future analysts who might be interested in utilising macro-level explanatory variables or capitalising more fully on the analytical options offered by multi-level modelling.

Our analysis thus replicates and extends earlier research on socioeconomic inequality in child health in the Czech Republic after 1989. Since we use somewhat different data and analytic procedures than have been used in this area so far, we will first have to test whether our models are able to replicate the results of earlier research. We will then investigate whether the identified trends persisted until 2007. Finally, we will assess whether the results are consistent across other measures of infant health not utilised before.

\section{Data, variables, and statistical method}

Vital statistics collected by the Czech Statistical Office are the data used in our analysis. The database contains data on all births to Czech mothers in the given years. The birth certificate records several characteristics of the newborn and his/ her parents. Information about the newborn includes sex, vitality, birth weight, length of gestation, parity, and the date of delivery. Recorded parental characteristics refer mostly to the mother-her age, marital status, education level, and the region (administrative district) of her permanent residence. ${ }^{2}$ The birth certificate also contains information about the father (age, education, etc.) in the case of married mothers. However, no information was recorded for cohabiting and other fathers until 2007. ${ }^{3}$

When the first segment of data was purchased there were a couple of problems. One was that the birth certificate database for the years before 1992 was not available in machine-readable format. Another was that researchers were not allowed direct access to the database and could only obtain multi-way tables of data. This was not an insurmountable analytic problem, since most of the variables are nominal or ordinal. Later, owing to legislative changes and progress in the conversion of older data into electronic format, we gained access to complete birth databases for the years 1990 and 2007 and extended the original dataset. Because we obtained data on two different occasions and in two different formats, we had to make some measurement compromises to harmonise all the records

\footnotetext{
2 'Permanent residence' is an administrative term referring to the place where a person is registered to vote, pay taxes, etc. It is not always necessarily a person's current residence. We only use data on the district (county) of the permanent residence. There are, to our knowledge, no data on how frequently 'permanent' and current addresses differ and how often each is located in a different administrative district.

3 The data collection procedures changed on 1 January 2007, and since then the birth certificate also routinely contains information on fathers, regardless of the mother's marital status. We do not use any information on fathers in this particular analysis.
} 
into one database (see Appendix A for the full details on the harmonisation of birth weight data).

We analyse data on all singleton ${ }^{4}$ births in 1990, 1992, 1994, 1996, 1998, 2000, 2002, 2004, and 2007. There were 912752 singleton births in these years. There were only minor problems with missing data. The mother's education was not recorded in 173 cases. Twelve of these missing observations (two in 1996, three in 2000, two in 2002, two in 2004, and three in 2007) occurred in mothers ages 17 or younger, who by the time they gave birth could only have completed elementary education, so in these 12 cases the missing values were re-coded as elementary education. The remaining 161 cases were deleted. ${ }^{5}$ There were no missing values for the other variables. This leaves us with 912591 singleton births, of which 909 803 were live births and the remainder stillbirths.

We use six different dependent variables in the analyses: vitality, length of gestation, and four variables based on birth weight (percentage distributions of our dependent variables are presented in Table 1). 'Vitality' is a dichotomous variable contrasting still (0) vs live (1) births. The Czech Statistical Office uses a variant of the WHO definition of live births based on observed signs of life. ${ }^{6} \mathrm{We}$ can see in Table 1 that the share of stillbirths first declined fairly rapidly, from $0.39 \%$ (in 1990) to $0.30 \%$ (in 1994), then bounced around somewhat until 1998, after which it continued to decline until its present (2007) level of $0.26 \%$.

'Length of gestation' is measured as the number of weeks between the mother's last menstrual period and childbirth. We use this information as a dichotomous variable of preterm (37 weeks and less) vs term births. Table 1 shows that the proportion of preterm newborn singletons was relatively stable until 2002. Between 1990 and 2002 the share of preterm singletons ranged from $7.7 \%$ to $8.8 \%$ without a discernible trend. However, by 2007 the share had grown to $10.5 \%$.

'Birth weight' is measured and recorded as the weight in grams on the birth certificate. We use it both as a continuous variable and in dichotomised versions.

\footnotetext{
${ }^{4}$ Multiple pregnancies more often result in adverse outcomes (i.e. preterm birth, low or very low birth weight). Therefore, we decided to exclude them from the analysis, which is a rather common practice [cf., e.g., Koupil et al. 2006; Koupilová et al. 1998, 2000; Raum et al. 2001].

${ }^{5}$ We carried out a logistic regression to find out whether the missing values can be predicted on the basis of other variables in the analysis. We estimated a set of models with all our dependent and independent variables as the predictors of the occurrence of missing values of the mother's education. Only district turned out to predict 'missingness' in any significant way.

${ }^{6}$ A live birth is (and has been throughout the studied period) defined as 'the expulsion or extraction of the foetus from the mother's body if the infant shows any sign of life and his/her birth weight is (a) higher than $1000 \mathrm{~g}$ or (b) lower than $1000 \mathrm{~g}$ and the infant survives 24 hours. Otherwise the birth is considered a stillbirth. The signs of life are breath, heartbeat, pulsation of the umbilical cord, or movement of voluntary muscles, regardless of whether or not the umbilical cord has been cut or the placenta is attached [Ministry of Health 1988].
} 
We use three different birth weight thresholds for the dichotomisation. First, we contrast low birth weight (2499 grams or less) with other (2500 grams or more) birth weights. Second, we contrast very low birth weight (1499 grams or less) with other birth weights. Finally, we contrast high birth weight (3500 grams or more) with other birth weights. Low and very low birth weight indicate a health disadvantage, while high birth weight is an advantageous health condition. According to Spencer [2003: 5-8], who reviewed findings from several European and American studies, children born with a weight between 3500 and 4500 grams have the lowest infant mortality. Rychtaříková [1999] identified a weight interval of between 3500 and 3999 grams as indicative of the best survival chances in Czech infants. Table 1 presents data on the distribution of categories of birth weight over time, which shows little change. For instance, the share of children with a low birth weight remains fairly constant across the entire period of observation, ranging from a low of $4.3 \%$ in 1998 to a high of 5.2\% in 2007. Similarly, there is not much of a trend in the relative incidence of other categories.

The main explanatory variable is the 'mother's education'. It is an ordinal variable distinguishing four levels of schooling: elementary, lower secondary (vocational), complete secondary, and tertiary. Education is measured at the time of the woman's delivery, so some mothers may not have completed their education at that time. We also utilise a number of control variables that are known to influence birth and pregnancy outcomes [cf., e.g., Spencer 2003; Koupil et al. 2006; Rychtaŕíková 1999]: the 'age of the mother' (split into the following categories: under 17 years, 18-19, 20-24 years, 25-29 years, 30-34 year, 35+ years), 'parity' (with four categories: 1, 2, 3, 4+), the 'sex' of the infant (male vs female), 'marital status' (never married, married, widowed, and divorced). Our multi-level statistical models use 'district' as a clustering (second-level) variable (there are 78 categories of district). ${ }^{7}$ The distribution of cases across the categories of independent variables is presented in Table $2 .^{8}$

We estimated the models for each year in our analysis $(1990,1992,1994,1996$, $1998,2000,2002,2004$, and 2007) to examine the trends in the estimated effect of the mother's education. We estimated two models for each of the dependent variables: the baseline model with just the mother's education as an explanatory variable, and the extended model with the whole set of controls. We used randomintercept models to account for the clustered data structure. ${ }^{9}$ For the continuous dependent variable, the two models can be formally written as:

\footnotetext{
7 The system of administrative districts has undergone some reforms during the period under observation. We use the district definitions that were valid as of 2007 in the analysis. Data collected before the reforms were modified and each birth was assigned to the district to which it would have belonged after the reform.

${ }^{8}$ Owing to the limited space of this article, here we do not report the distribution of cases by district.

9 In an ancillary analysis (not reported here) we also entered the district as fixed-effects into the analysis. The results were not significantly different.
} 


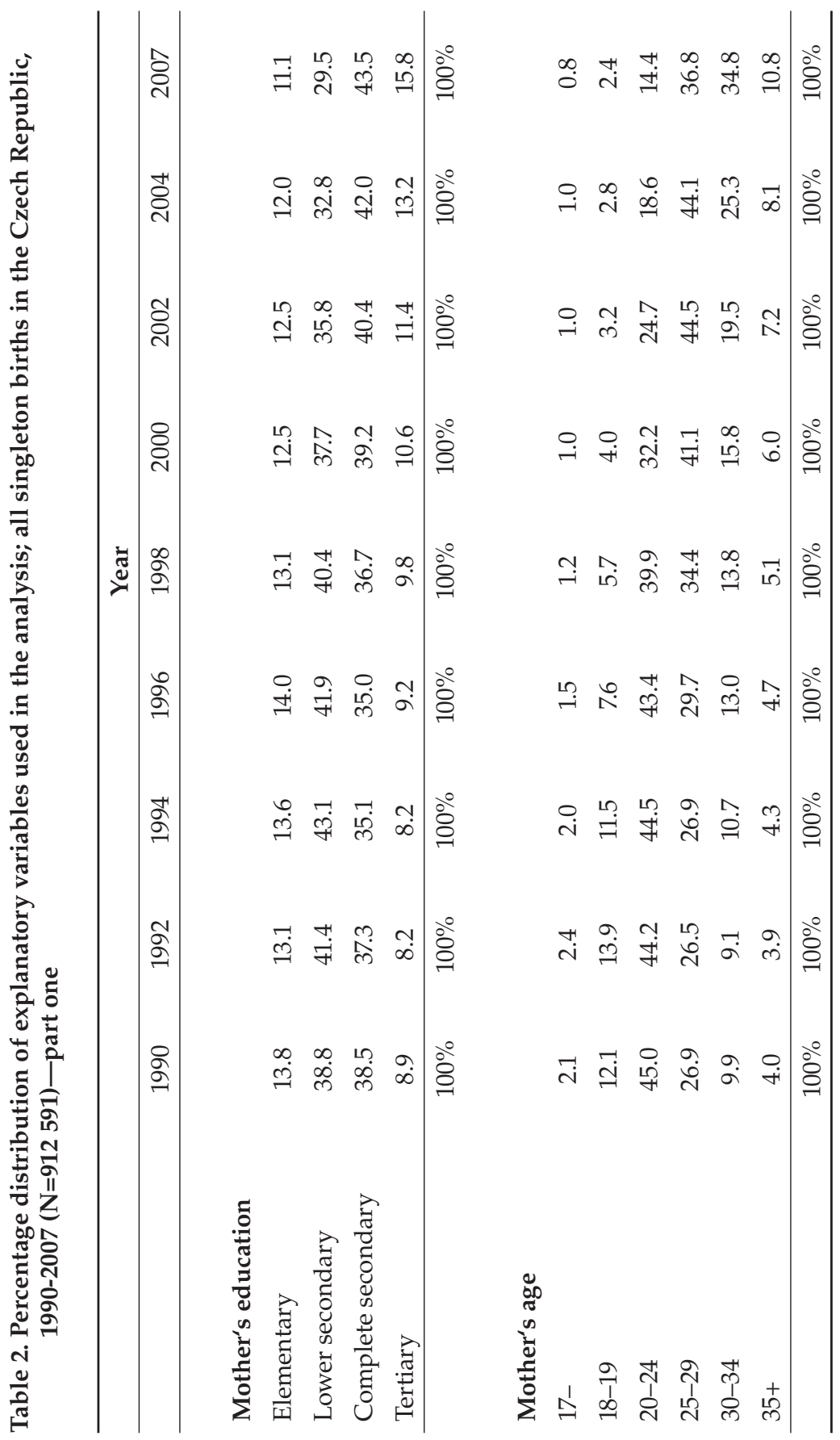




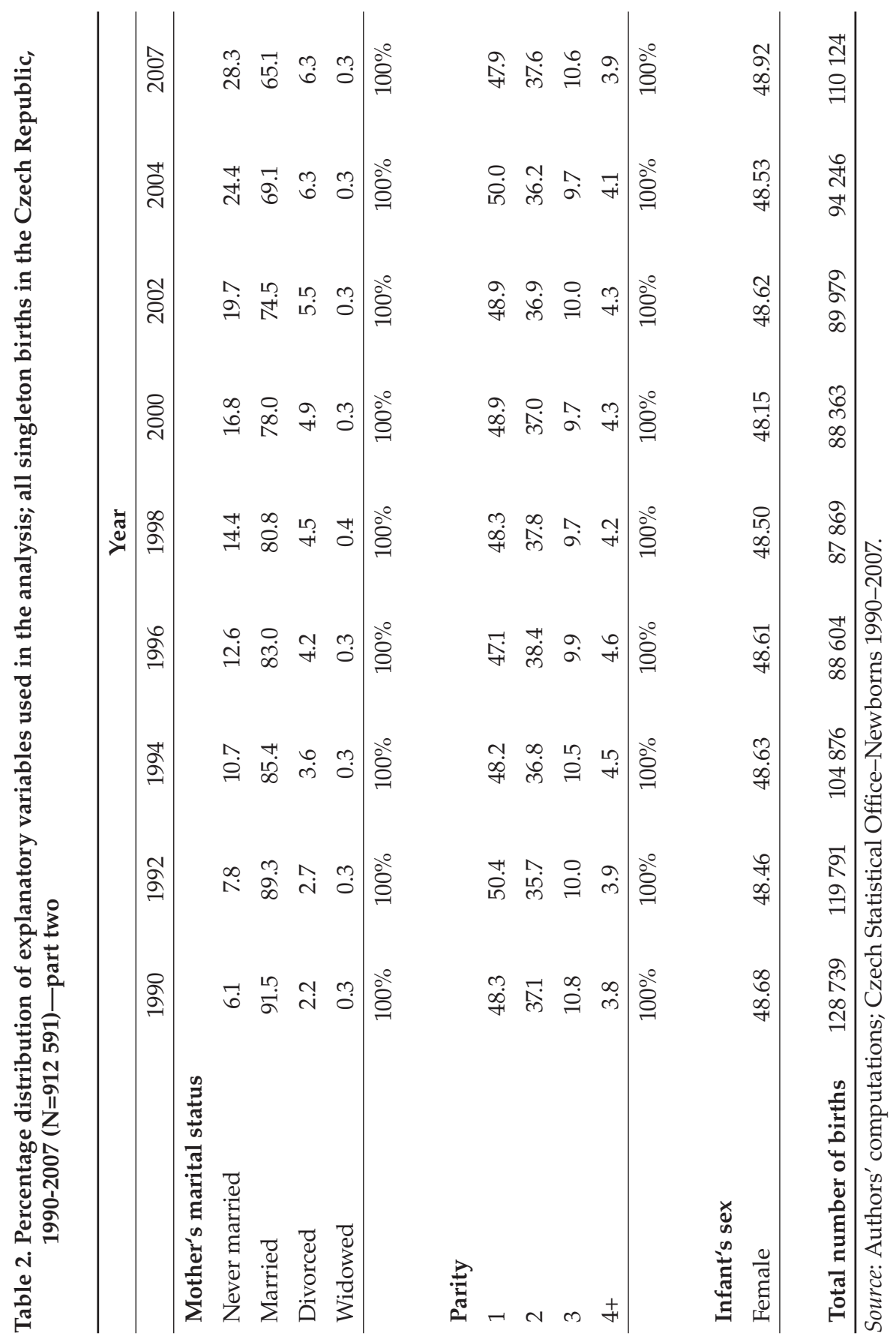


Baseline model (without controls):

$Y_{i j}=\beta_{0 j}+\beta_{1}^{*} E d 2+\beta_{2}^{*} E d 3+\beta_{3}^{*} E d 4+e_{i j}$

Extended model (with controls):

$Y_{i j}=\beta_{0 j}+\beta_{1}^{*} E d 2_{i}+\beta_{2}^{*} E d 3_{i}+\beta_{3}^{*} E d 4_{i}+\sum_{k=1}^{K} \beta_{k}^{*} X_{k i}+e_{i j}$

In these equations, $Y_{i j}$ denotes birth weight (in grams) of the $i^{\text {th }}$ infant in district $j, E d 2$ is the indicator variable for vocational education, $E d 3$ indicates complete secondary education, and $E d 4$ is the indicator for university education. Also, $\beta_{0 j}$ is a random intercept and $e_{i j}$ is the prediction error. Finally, $\beta_{1}, \beta_{2}, \beta_{3}$ are the expected differences in birth weight between, respectively, vocational, complete secondary, and university education, and the reference category of education (elementary education). In Equation $2, X_{k i}$ is a vector of $K$ control variables and $\beta_{k}$ are their estimated effects.

We estimated each model separately for each year for which there are data. We used the estimated coefficients $\beta_{1}, \beta_{2}, \beta_{3}$ from both the baseline and the extended models as indicators of the extent of inequality in birth weight each year. ${ }^{10}$ By comparing these coefficients across years, it is possible to observe whether inequality is increasing, stable, or declining. Below the estimated coefficients are presented in a series of figures that reveal any trends. The precise values of all the estimated $\beta$ s are presented in Appendix B.

Both the baseline and the extended models can analogously be rewritten for dichotomous dependent variables [see, e.g., Hox 2002: Chapter 6; Raudenbush and Bryk 2002: 294-309], and the estimated coefficients can be utilised in a similar fashion to describe trends in socioeconomic inequality in the log odds of stillbirth, preterm birth, or very low, low, and high birth weight. ${ }^{11}$

\footnotetext{
${ }^{10}$ We chose to parameterise the effects of education this way, since a preliminary analysis revealed that the largest gap in child health by maternal education is between mothers with elementary education on the one hand and mothers with all other levels of education on the other hand.

${ }^{11}$ We report only the estimated effects of the mother's education. We report neither the effects of other variables in the analysis, nor other characteristics of our multi-level models (i.e. variance components), since these are of little substantive interest. Similarly, we did not compare the baseline and extended models statistically because we have population data, and statistical inference is therefore of limited value. We employed STATA 11 MP's commands 'xtreg' and 'xtlogit' to obtain all the estimates presented in this article.
} 


\section{Results}

Figure 1 shows the expected difference in average birth weight in grams between infants born to mothers with lower secondary, upper secondary, and tertiary education compared to the reference category of elementary education. Infants born to mothers with lower secondary education were, on average, 129 grams heavier in 1990 than infants born to mothers with elementary education. The contrast between mothers with university and mothers with elementary education was 186 grams in the same year. The disparities grew until 1996 and later stabilised at 178-188 grams (elementary vs lower secondary education) and 236-240 grams (elementary vs university educated mothers) with no clear trend. By 2007, the elementary education disadvantage fell to 168 grams, 197 grams, and 213 grams compared to lower secondary, upper secondary, and university education, respectively. Gross educational disparities were thus larger in 2007 than in 1990. When control variables were added to the model, inequalities in birth weight were attenuated (see the right panel of Figure 1), yet the basic pattern persisted. Once more we can see a rise in educational disparities, peaking in 2004, and then a decrease in the last year. The net education gap was again larger in 2007 than in 1990. In sum, the disparity in mean birth weight by mother's education increased after 1990. However, the rise did not continue after the mid-2000s and currently there seem to be some signs of a reversal. When controlling for additional vari-

Figure 1. Estimated effects of lower secondary, complete secondary, and university education of the mother on birth weight; all live singleton births in the Czech Republic, selected years from 1990 to 2007 (N=909 803)

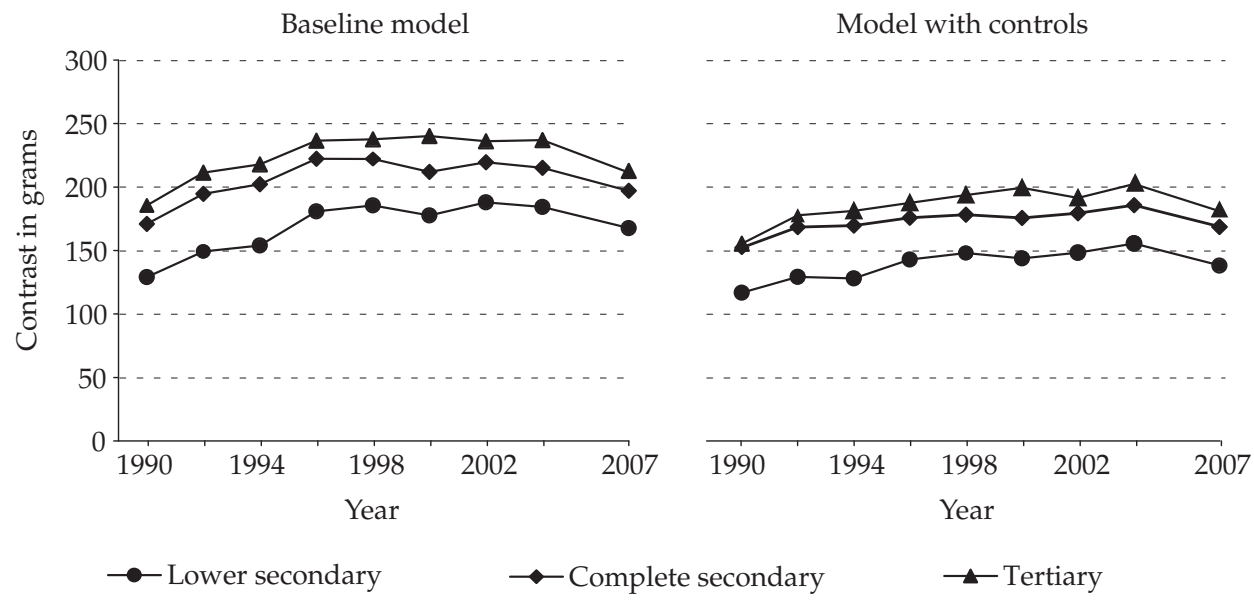

Source: Authors' computations; Czech Statistical Office-Newborns 1990-2007.

Note: estimates are based on a random-intercept multi-level regression model. 
Figure 2. Estimated effects of lower secondary, complete secondary, and university education of the mother on the log odds of low birth weight; all live singleton births in the Czech Republic, selected years from 1990 to 2007 $(\mathrm{N}=909$ 803)

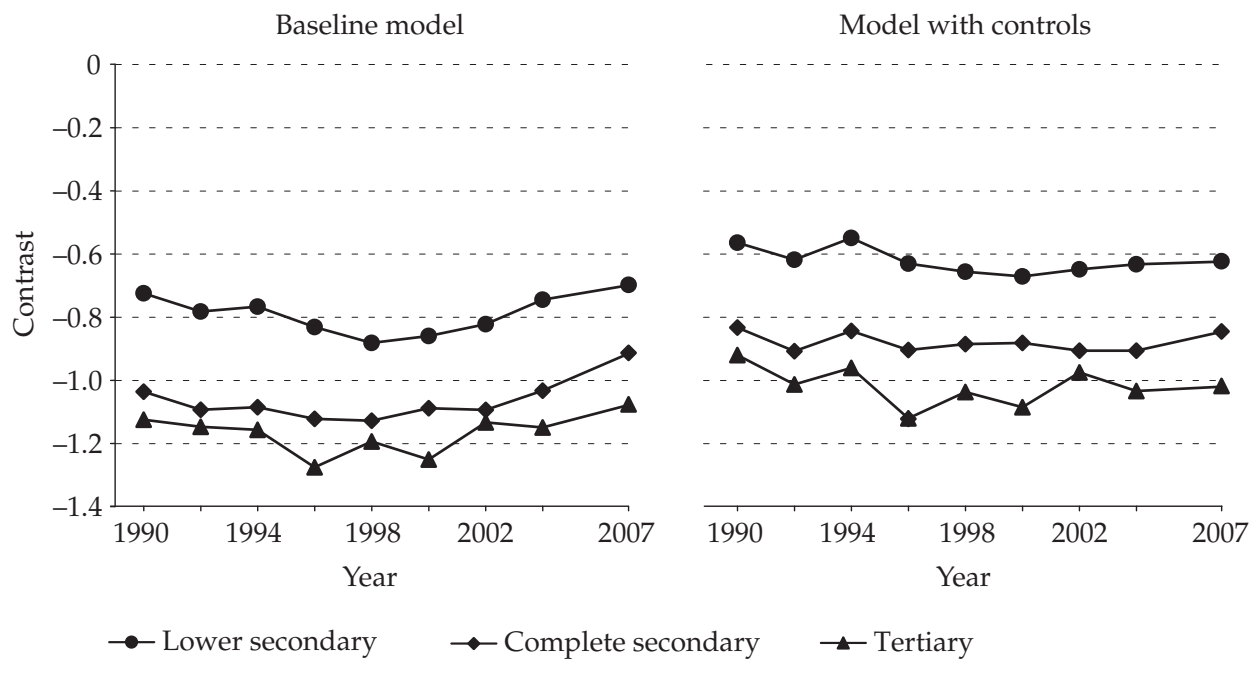

Source: Authors' computations; Czech Statistical Office-Newborns 1990-2007.

Note: estimates are based on a random-intercept multi-level logistic regression model.

ables, the increase in the 1990s is less intense, yet it is still quite apparent. We can again see an indication of attenuating inequality between 2004 and 2007. Despite this last data point, there is more inequality in birth weight in the late 2000s than there was in the early 1990s.

Figure 2 presents the beta coefficients for the models with the binary indicator of low birth weight as the dependent variable. The interpretation of these coefficients is not as intuitive as the difference in grams in the previous analysis, since the figure depicts differences in the expected log odds. The biggest gap is again between elementary and any higher education of the mother. According to the baseline model, the disparities increased in the first half of the 1990s and then lessened steadily until they were even smaller than they had been initially. When control variables are added, the trend is much less clear. It appears that the effects of lower secondary education and of university education grew overall, while the effect of upper secondary education stayed the same.

Figure 3 shows the trend in the effect of maternal education on the log odds of very low birth weight. The lines in the figure are not very smooth owing to the low absolute numbers of newborns in this weight category. The baseline model documents the overall reduced educational disparities between 1990 and 2007. 
Figure 3. Estimated effects of lower secondary, complete secondary, and university education of the mother on the log odds of very low birth weight; all live singleton births in the Czech Republic, selected years from 1990 to 2007 $(\mathrm{N}=909$ 803)

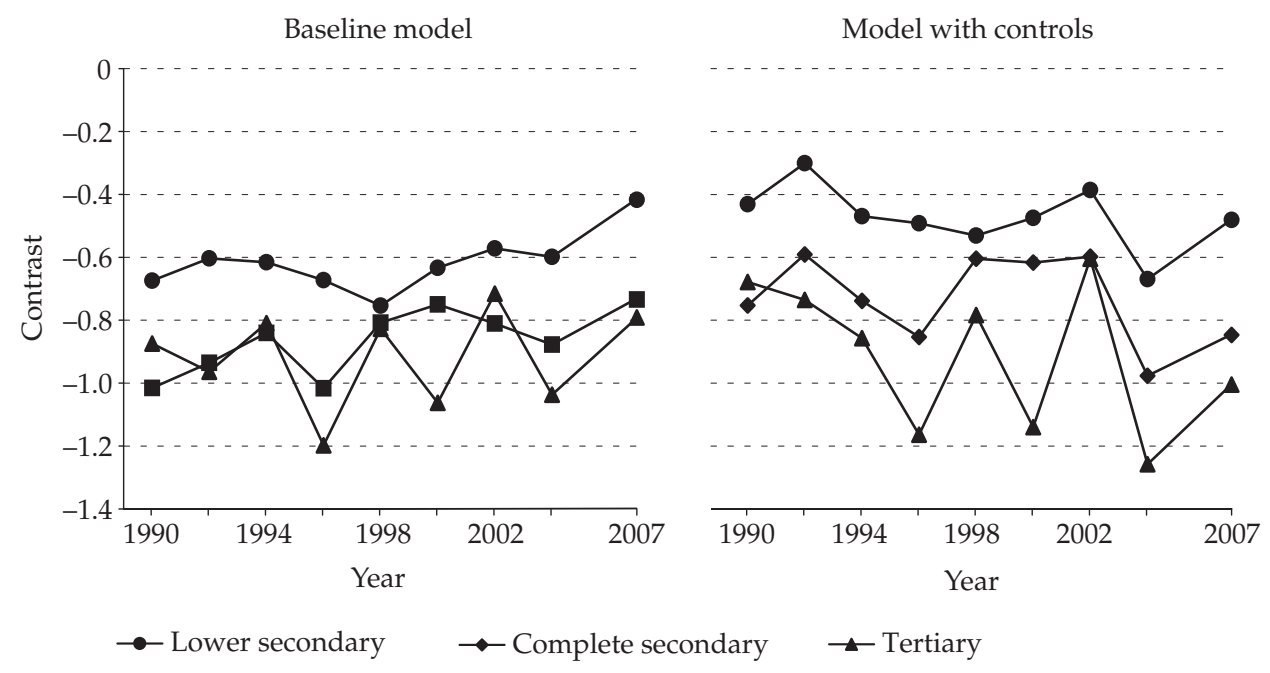

Source: Authors' computations; Czech Statistical Office-Newborns 1990-2007.

Note: estimates are based on a random-intercept multi-level logistic regression model.

They seem to weaken after 1998, to which time they had been relatively stable. In contrast, the extended model shows the opposite pattern. Despite the oscillatory character of the lines, there is a visible trend towards greater inequality. When mothers with elementary and lower secondary education are compared, the disparity increases from -0.43 to -0.48 . The contrast between children born to mothers with elementary education and those born to mothers with university education rose from -0.68 to -1.00 . The net effect of maternal education on the probability of very low birth weight has thus strengthened since 1990.

Figure 4 presents the results of the analysis of high vs other birth weight. The gross disparities between infants born to mothers with elementary and higher levels of education sharply increased between 1990 and 1998. The contrast between elementary and lower secondary education rose from 0.38 to 0.64 , and the disparity with tertiary education increased from 0.56 to 0.83 . The large differences persisted until 2004 and then dropped to 0.58 for elementary vs lower secondary education of the mother and to 0.70 for the contrast between elementary and university maternal education. But these disparities are still higher than the initial ones. Similarly, the net education effects (see the right panel in Figure 4) were larger in 2007 than in 1990. 
Figure 4. Estimated effects of lower secondary, complete secondary, and university education of the mother on the log odds of high birth weight; all live singleton births in the Czech Republic, selected years from 1990 to 2007 $(\mathrm{N}=909$ 803)

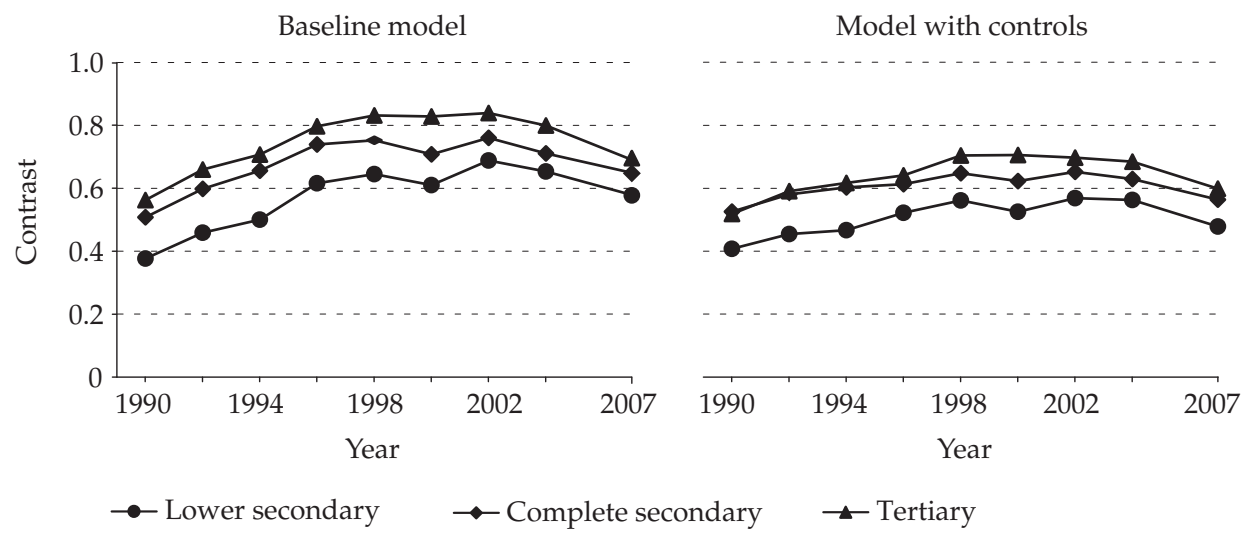

Source: Authors' computations; Czech Statistical Office-Newborns 1990-2007.

Note: estimates are based on a random-intercept multi-level logistic regression model.

Figure 5. Estimated effects of lower secondary, complete secondary, and university education of the mother on the log odds of preterm delivery; all live singleton births in the Czech Republic selected years from 1990 to 2007 $(\mathrm{N}=909$ 803)

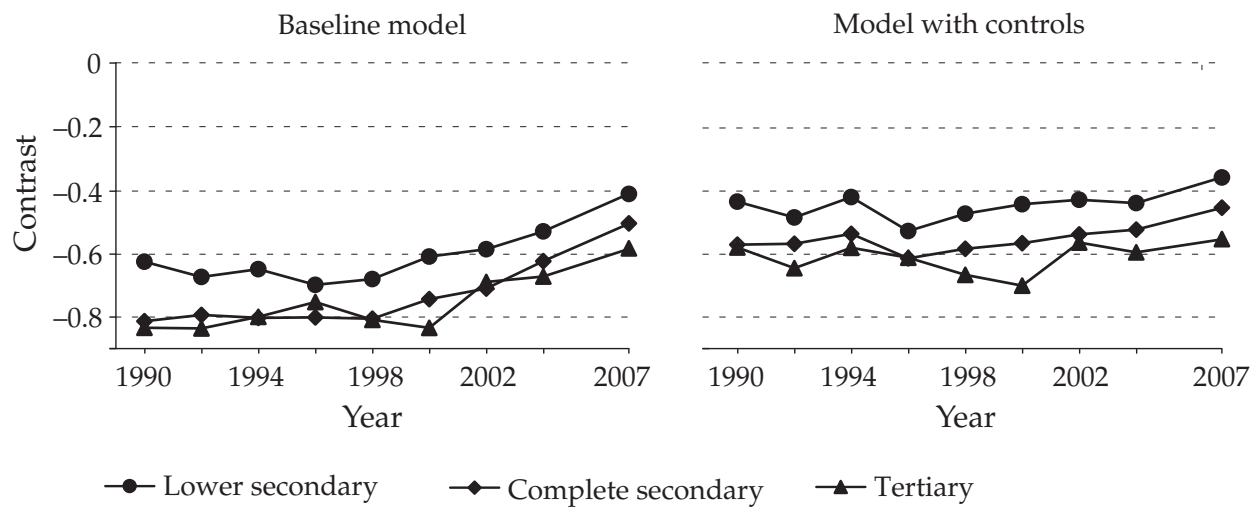

Source: Authors' computations; Czech Statistical Office-Newborns 1990-2007.

Note: estimates are based on a random-intercept multi-level logistic regression model. 
Figure 6. Estimated effects of lower secondary, complete secondary, and university education of the mother on the log odds of stillbirth; all singleton births in the Czech Republic selected years from 1990 to 2007 ( $N=912$ 591)

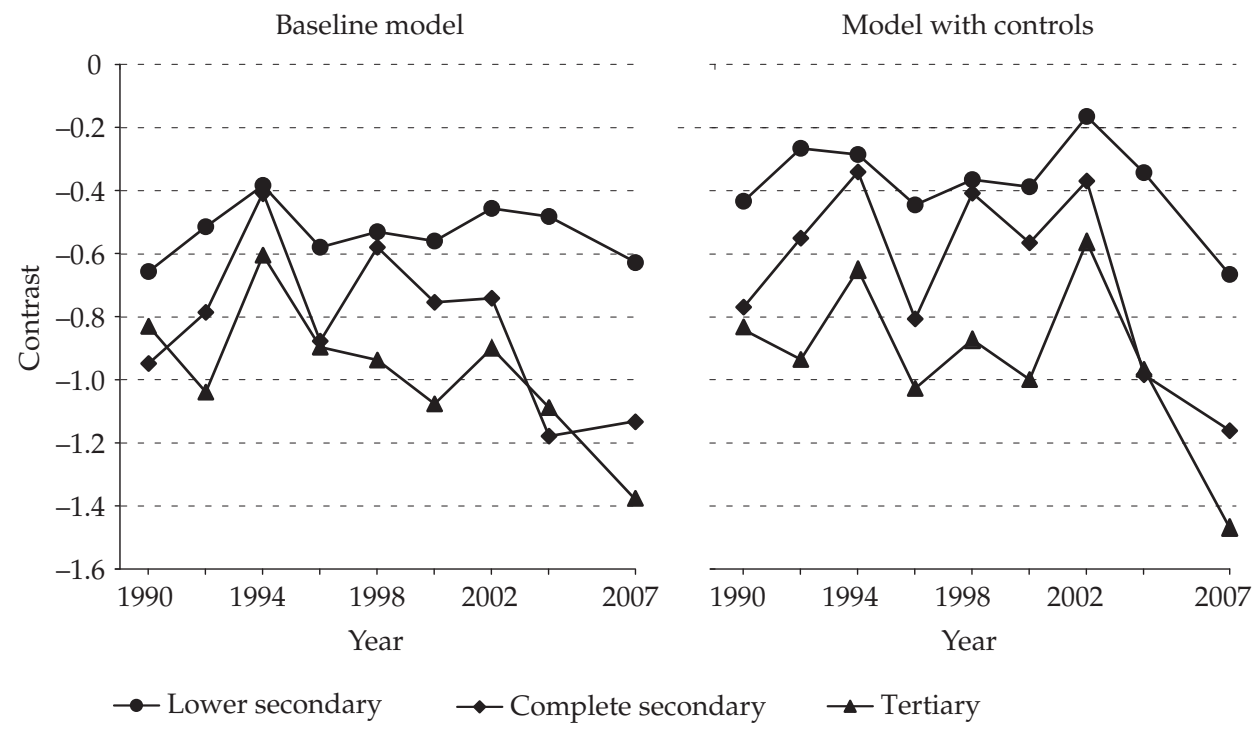

Source: Authors' computations; Czech Statistical Office-Newborns 1990-2007.

Note: estimates are based on a random-intercept multi-level logistic regression model.

Now we will focus on another proxy for a newborn's health, the length of the pregnancy. The results are shown in Figure 5. Both the net and gross education disparities in the log odds of preterm birth were stable in the 1990s and weakened significantly after 1998. This trend is rather robust when we consider the baseline model. The contrast between elementary and lower secondary education decreased from -0.62 to -0.41 and the difference between elementary and tertiary education decreased from -0.83 to -0.58 . However, the net improvement is much more modest. Thus, most of the decrease in inequality in preterm birth is explained by the control variables.

Finally, we proceed to the analysis of how the mother's education influences the vitality of the foetus. These results are presented in Figure 6. Again we see that - as in the case of very low birth weight - the low number of cases of interest (i.e. stillbirths) causes the lines to fluctuate substantially. Nevertheless, it is still possible to observe a notable trend. There clearly is more inequality in the vitality of the foetus in the second half of the 2000s than there was in the early 1990s, and this applies with respect to both the gross and the net effects of maternal education. 


\section{Conclusion}

Above we explored the trends in socioeconomic inequality in birth and pregnancy outcomes in the Czech Republic between 1990 and 2007. This was done using six different dependent variables - all of which are generally and widely agreed to be reasonable approximations of child health and future life chances (four measures of birth weight, vitality, and length of gestation). We employed mother's education as a proxy for the socioeconomic status of the family in which the child was conceived and born. We have limited our analysis to singleton births. Since we used hierarchical linear models to account for the clustered data structure, we believe that this analysis offers more credible evidence of trends than what has been supplied in earlier papers on the subject.

Maternal education seems to have a fairly strong stratifying effect on pregnancy and birth outcomes. Interestingly, the most salient gap in health is between mothers with elementary education and all other mothers. This major stratification division played out regardless of the specific outcome variable and persisted through the period under study. We would argue that both sociologists and demographers should pay more attention to the least educated mothers, their (non-)decisions to conceive a child, and the circumstances of their pregnancy and subsequent life situation. While inequality in child health by maternal education can typically be partially explained by other variables (most notably age and marital status), the net effect of education is still remarkably salient. Factors related directly to educational attainment (most notably the amount of economic resources) appear to be responsible for observed levels of inequality. Nevertheless, changes in the age patterns of fertility and in the marriage market behaviour of women can also make an important contribution to our understanding of the changing patterns of child health stratification. Other variables that may play an important role in shaping inequality (and that were not included in our analysis) are migrant status and ethnic minority status. Bobák et al. [2005], for example, observed substantial disparities in birth outcomes between Roma and non-Roma newborns, which, although largely explained by maternal education, persisted after controlling for other predictors.

We have seen that inequality in the various birth weight measures has increased. The increase occurred mostly in the 1990s, but this trend did not continue into the 2000s. There even seems to be some indication that inequality was declining by the end of the 2000s. Yet, this reversal is indicated mostly by data points at the very end of our time series. Therefore, caution should be exercised before making any strong generalising conclusions in this regard. While all the measures based on child birth weight showed an increase in inequality, this tendency is most pronounced in the analysis of birth weight measured as a continuous variable and in the most advantageous weight category of 3500 and more grams. This suggests that the socioeconomic transformation most significantly impacted the health of infants from the least privileged social group in the sense that they became less likely to be born in the most advantageous weight category, 
while they did not experience an increase in their exposure to the risk of the most adverse outcomes.

Inequalities in stillbirths and preterm births display somewhat inconsistent trends. Stratification of the odds of premature delivery showed some reduction (or no trends). Inequality in the vitality of the foetus became more strongly linked to the mother's education. Yet, this last finding-more than any other piece of empirical evidence in this article-is the least robust of all, since the number of stillbirths is extremely low.

Our results only partly confirm the findings of Koupilová et al. [1998], who studied educational differences in birth weight, preterm birth, and infant death from 1989 to 1996. Like that study, our analysis found rising educational differences in birth weight, but did not confirm the growing disparity in the length of pregnancy. We have no explanation as to why our results do not replicate earlier analyses more precisely.

Overall, the results provided more evidence of growing inequality in birth and pregnancy outcomes than of declining stratification. In most cases the growth in inequality occurred in the first half of the 1990s. Therefore, we could tentatively link this trend to the costs of the early stage of the social transition after 1989, when the amount of stress and uncertainty related to new social and economic phenomena spread throughout society. We are unsure why inequality stabilised towards the late 1990s. Perhaps some process of psychological adjustment took place in the 1990s that made people less vulnerable to stressors, as they began to understand the new situation and became more resistant to stress. We hypothesise that socioeconomically advantaged individuals made the adjustment faster, and individuals with fewer resources adjusted at a slower pace. This 'selective adjustment hypothesis' would explain why inequality increased initially and then stabilised at a new level.

It is also possible that the (potentially) most vulnerable women within each education group may have increasingly opted to remain childless. It is possible that vulnerability may not relate directly to economic resources, but may reflect, for instance, the level of social support a person has, and that may vary within social strata. Women across education levels may differ in their cognitive abilities to assess their social situations and the life chances of their children. If more educated women are faster to understand and respond to the new circumstances in post-socialist society, this learning and decision-making process could lead to increasing and then stabilising inequality levels. We call this alternative explanation 'selective childlessness'. Selective childlessness could operate through two distinct mechanisms: selective reproduction planning and selective abortion. There is some evidence to show that selective reproduction planning does indeed occur in the Czech Republic. Little is known, however, about the selectivity of abortion.

Hašková [2009: 97-101] has shown that Czech women and men with different socioeconomic status consider different factors when deciding whether (and 
when) to have children. Respondents with higher education and higher income (personal as well as household income) pay more attention to what Hašková calls situational factors, while those with low education and income adhere more to the desire-for-a-child factor. The situational factor, preferred by groups with higher socioeconomic status, relates to partnership and to the health and the work conditions of both potential parents (see also Pakosta [2009] for a more quantitative picture of the fertility preferences of contemporary Czechs). By timing childbirth according to these conditions (i.e. most probably delaying it until after the stressful transition period in the 1990s), high-status families may have avoided potential health risks for their children more effectively than low-status families. Thus, women who gave birth in the 1990s (and especially the early 1990s) may have selectively been recruited more from those who either considered their situation optimal for having children or just wanted to have children without thoroughly deliberating their situation (Bartošová [2009] depicts the heterogeneity of female reproductive strategies in her ethnographic research showing, among other things, that some women 'want to have children no matter what'). The result is that children born to the former group of mothers may have obtained a health advantage and those in the latter may have been exposed to increased risk, thus leading to a rise in inequality.

Our understanding of how social standing influences pregnancy and birth outcomes is still limited. Measuring family background solely on the basis of maternal education offers an incomplete picture of the resources that families have available to them to bring up a healthy child, as it overlooks the influence of the father's contribution to the social standing of a family [cf. Rychtaříková 2001]. Moreover, family arrangements may play an important role in influencing the health of children [cf. Bird et al. 2000], as well as and in interaction with parental statuses. The observed increase in socioeconomic inequality in the health of newborns should therefore be considered as a starting point for more thorough research on the health consequences of family background for children.

MARTINA ŠTíPKOVÁ is a PhD student in sociology at the Faculty of Social Sciences, Charles University in Prague. She also works as a teaching assistant at the Faculty of Philosophy and Arts, University of West Bohemia in Pilsen. Her research focuses on social stratification, family arrangements, and health.

MARTIN KREIDL is associate professor of sociology at the Faculty of Social Studies, Masaryk University in Brno. His research deals with social stratification and social demography, often in a comparative perspective. 


\section{References}

Adeyi, Olusoji, Gnanaraj Chellaraj, Ellen Goldstein, Alexander Preker and Dena Ringold. 1997. 'Health Status during the Transition in Central and Eastern Europe: Development in Reverse?' Health Policy and Planning 12: 132.

Bartley, Mel, David Blane and George D. Smith. 1998. The Sociology of Health Inequalities. Oxford, Malden: Wiley-Blackwell.

Bartošová, Michaela. 2009. 'Ženy po třicítce—příklad specifických reprodukčních strategií a jejich zdrojü.' (Women over Thirty-Specific Reproductive Strategies and Their Sources) Sociologický časopis/Czech Sociological Review 45 (1): 147-176.

Bird, Sheryl Thorburn, Anjani Chandra, Trude Bennet and S. Marie Harvey. 2000. 'Beyond Marital Status: Relationship Type and Duration and the Risk of Low Birth Weight.' Family Planning Perspectives 32 (6): 281-287.

Blaxter, Mildred 1991. 'Fifty Years On-Inequalities in Health.' Population Studies 45 (Population Research in Britain: Supplement): 69-94.

Blažek, Jiří and Dagmar Dzúrová. 2000. 'The Decline of Mortality in the Czech Republic during the Transition: A Counterfactual Case Study.' Pp. 303-327 in The Mortality Crisis in Transitional Economies, edited by Giovanni Andréa Cornia and Renato Paniccià. Oxford: Oxford University Press.

Bobak, Martin, Hynek Pikhart and Ilona Koupilová. 2000. 'Maternal Socioeconomic Characteristics and Infant Mortality from Injuries in the Czech Republic 1989-92.' Injury Prevention 6: 195-198.

Bobak, M., J. Dejmek, I. Solansky and R. J. Sram. 2005. ‘Unfavourable Birth Outcomes of the Roma Women in the Czech Republic and the Potential Explanations: A Population-based Study.' BMC Public Health 5: 106.

Bryndová, Lucie, Kateřina Pavloková, Tomáš Roubal, Martina Rokosová and Matthew Gaskins. 2009. 'Czech Republic: Health System Review.' Health Systems in Transition 11 (1): 1-122. Retrieved 26 July 2010 (http://www.euro.who.int/_data/assets/ pdf_file/0010/97633/E92968.pdf).

Carlson, Elwood, Jan M. Hoem and Jitka Rychtaříková. 1999. ‘Trajectories of Fetal Loss in the Czech Republic.' Demography 36: 327-337.

Chen, Lincoln C, Friederike Wittgenstein and Elizabeth McKeon. 1996. 'The Upsurge of Mortality in Russia: Causes and Policy Implications.' Population and Development Review 22: 517-530.

Cockerham, William C. 1997. 'The Social Determinants of the Decline of Life Expectancy in Russia and Eastern Europe: A Lifestyle Explanation.' Journal of Health and Social Behavior 38: 117-130.

Cockerham, William C. 2007. Social Causes of Health and Disease. Cambridge, Malden: Polity Press.

Conley, Dalton and Neil G. Bennet. 2002. 'Birth Weight and Income: Interactions Across Generations.' Journal of Health and Social Behavior 42: 450-465.

Conley, D., K. W. Strully and N. G Bennett. 2003. The Starting Gate: Birth Weight and Life Chances. Berkeley, Los Angeles, CA: University of California Press.

Cornia, Giovanni A. and Renato Paniccià (eds.). 2000. The Mortality Crisis in Transitional Economies. Oxford: Oxford University Press.

Czech Statistical Office. 2008. Czech Demographic Handbook 2007. Prague: Český statistický úřad. Retrieved 26 July 2010 (http://www.czso.cz/csu/2008edicniplan.nsf/ engpubl/4032-08-2007).

Czech Statistical Office. 2009. Demographic Yearbook of the Czech Republic 2008. Prague: Český statistický úřad. Retrieved 26 July 2010 (http://www.czso.cz/csu/ 2009edicniplan.nsf/engpubl/4019-09-2008). 
Czech Statistical Office. 2010. ČR od roku 1989 v čislech (Czech Republic since 1989 in Numbers). Prague: Český statistický úřad. Retrieved 26 July 2010 (http://www.czso. cz/csu/redakce.nsf/i/cr_od_roku_1989\#01).

Federal State Statistics Service. 2009. 'Russia in Figures.' Retrieved 8 July 2010 (http://www.gks.ru/bgd/regl/b09_12/IssWWW.exe/stg/d01/05-08.htm).

Frýdmanová, Marie, Kamil Janáček, Petr Mareš and Tomáš Sirovátka. 1999. 'Labour Market and Human Resources.' Pp. 21-43 in Ten Years of Rebuilding Capitalism. Czech Society After 1989, edited by Petr Matějů and Jiří Večerník. Prague: Academia.

Gortmaker, Steven L. and Paul H. Wise. 1997. 'The First Injustice: Socioeconomic Disparities, Health Services Technology, and Infant Mortality.' Annual Review of Sociology 23: 147-170.

Grigoriev, P., V. M. Shkolnikov, E. M. Andreev, D. Jasilionis, D. A. Jdanov, F. Meslé and J. Vallin. 2010. 'Mortality in Belarus, Lithuania, and Russia: Divergence in Recent Trends and Possible Explanations.' European Journal of Population/Revue européenne de Démographie 26: 245-274.

Habicht, Jarno, Raul-Allan Kiivet, Triin Habicht and Anton E. Kunst. 2009. 'Social Inequalities in the Use of Health Care Services after 8 Years of Health Care ReformsA Comparative Study of the Baltic Countries.' International Journal of Public Health 54: 250-259.

Hamplová, Dana and Martin Kreidl. 2006. 'Globalization and Men's Occupational Mobility in the Czech Republic in the 1990s.' Pp. 275-302 in Globalization, Uncertainty and Men's Careers: An International Comparison, edited by Hans-Peter Blossfeld and H. Hofmeister. Cheltenham: Edward Elgar Press.

Hasmanová Marhánková, Jaroslava and Ema Hrešanová. 2008. ‘Nové trendy v českém porodnictví a sociální nerovnosti mezi rodičkami.' (New Trends in the Czech Birthing System and Emerging Social Inequalities among Birthing Women) Sociologický časopis/ Czech Sociological Review 44 (1): 87-111.

Hašková, Hana. 2009. Fenomén bezdětnosti. (The Phenomenon of Childlessness) Prague: Sociologické nakladatelství.

Hašková, Hana and Zuzana Uhde (eds.). 2009. Women and Social Citizenship in Czech Society: Continuity and Change. Prague: Sociologický ústav AV ČR.

Hiršl, Miroslav. 2004. 'Příspěvky Českého státu rodinám na náklady spojené s výchovou dětí.' (Contributions Provided by the Czech State to Families Raising Children) Demografie 46: 166-176.

Hox, Joop. 2002. Multilevel Analysis. Techniques and Applications. Mahwah: Lawrence Erlbaum Associates.

Katrňák, Tomáš, Martin Kreidl, Václa Kulhavý and Tomáš Sirovátka. 2008. 'Factors Influencing the Position of Young People on the Labour Market and Changes in Mobility Chances in the Czech Republic.' TransEurope Working Paper 3/2008. Bamberg: Otto-Friedrich-University Bamberg. Retrieved 26 July 2010 (http://www.transeuropeproject.org/UserFiles/File/Papers/TransEurope_WP3_Katrnak_et_al.pdf).

Keune, Maarten. 2003. 'Capitalist Divergence and Labour Market Flexibility in the Czech Republic and Hungary: A Comparative Analysis of Standard and Non-standard Employment.' Sociologický časopis/Czech Sociological Review 39 (6): 795-813.

Kocourková, Jiřina. 2008. 'Současný baby-boom v České republice a rodinná politika.' (The Current 'Baby-boom' in the Czech Republic and Family Policy) Demografie 50: 240-249.

Koupil, Ilona, Kaja Rahu, Mati Rahu, Helle Karro and Denny Vagero. 2006. 'Major Improvements, but Persisting Inequalities in Infant Survival in Estonia 1992-2002.' The European Journal of Public Health 17: 8. 
Koupilová, Ilona, Martin Bobák, Jan Holčík, Hynek Pikhart and David A. Leon. 1998. 'Increasing Social Variation in Birth Outcomes in the Czech Republic after 1989.' American Journal of Public Health 88: 1343-1347.

Koupilová, Ilona, Kaja Rahu, M. Rahu, Helle Karro and David A. Leon. 2000. 'Social Determinants of Birthweight and Length of Gestation in Estonia during the Transition to Democracy.' International Journal of Epidemiology 29: 118-124.

Kramer, Michael S., Louise Séguin, John Lydon and Lise Goulet. 2000. 'Socio-economic Disparities in Pregnancy Outcome: Why Do the Poor Fare So Poorly?' Paediatric and Perinatal Epidemiology 14: 194-210.

Krebs, Vojtěch. 2005. Sociální politika. (Social Policy) Prague: Aspi.

Mareš, Petr and Ladislav Rabušic. 1996. 'K měření subjektivní chudoby v české společnosti.' (The Subjective Perception of Poverty in the Czech Republic) Sociologický časopis 32: 297-315.

Mareš, Petr, Tomáš Sirovátka and Jiří Vyhlídal. 2003. ‘Dlouhodobě nezaměstnaní-životní situace a strategie.' (The Long-term Unemployed-Living Conditions and Strategies) Sociologický časopis/Czech Sociological Review 39 (1): 37-54.

Marmot, Michael. 2004. Status Syndrome: How Your Social Standing Directly Affects Your Health and Life Expectancy. New York: Bloomsbury \& Henry Holt.

Marmot, Michael and Martin Bobak. 2000. 'Psychosocial and Biological Mechanisms behind the Recent Mortality Crisis in Central and Eastern Europe.' Pp. 127-148 in The Mortality Crisis in Transitional Economies, edited by Giovanni Andréa Cornia and Renato Paniccià. Oxford: Oxford University Press.

Matějů, Petr and Martin Kreidl. 2001. 'Rebuilding Status Consistency in a PostCommunist Society. The Czech Republic 1991-1997.' Innovation 14: 17-34.

Meslé, France. 2004. 'Mortality in Central and Eastern Europe.' Demographic Research Special 2: 45-70.

Ministry of Health. 1988. Vyhláška Ministerstva zdravotnictvi č. 11/1988. (The Ministry of Health Care Code No. 11/1988) Prague: Ministry of Health.

Pakosta, Petr. 2009. 'Proč chceme děti: hodnota dítěte a preferovaný počet dětí v České republice.' (Why We Want Children: The Value of Children and the Preferred Number of Children in the Czech Republic) Sociologický časopis/Czech Sociological Review 45 (5): 899-934.

Pikhart, Hynek, Drbohlav Dusan and Dagmar Dzurová. 2010. 'The Self-Reported Health of Legal and Illegal/Irregular Immigrants in the Czech Republic.' International Journal of Public Health 55: 401-411.

Raudenbush, Stephen W. and Anthony S. Bryk. 2002. Hierarchical Linear Models. Applications and Data Analysis Methods. Thousand Oaks, London, New Delhi: SAGE.

Raum, Elke, Birgit Arabin, Martin Schlaud, Ulla Walter and Friedrich W. Schwartz. 2001. 'The Impact of Maternal Education on Intrauterine Growth: A Comparison of Former West and East Germany.' International Journal of Epidemiology 30: 81-87.

Rychtaříková, Jitka. 1999. 'Sociální a biologické faktory kojenecké úmrtnosti.' (Social and Biological Factors of Infant Mortality) Demografie 41: 95-104.

Rychtaříková, Jitka. 2001. 'Do Maternal and Paternal Characteristics Perform Similar Roles in Adverse Pregnancy Outcome and Infant Survival?' Acta Universitatis Carolinae: Geographica 36: 77-94.

Rychtař́ková, Jitka and George J. Demko. 2001. 'Inequalities in Infant Survival: An Analysis of Czech Linked Records.' European Journal of Population/Revue européenne de Démographie 17: 323-342.

Shkolnikov, Vladimir M., David A. Leon, Sergey Adamets, Eugeniy Andreev and Alexander Deev. 1998. 'Educational Level and Adult Mortality in Russia: An Analysis of Routine Data 1979 to 1994.' Social Science E Medicine 47: 357-369. 
Sobotík, Zdeněk and Jitka Rychtaříková. 1992. 'Úmrtnost a vzdělání v České republice.' (Mortality and Education in the Czech Republic) Demografie 34: 97-104.

Spencer, Nick. 2003. Weighing the Evidence: How Is Birthweight Determined? Oxon: Radcliffe Publishing.

Spencer, Nick and Catherine Law. 2007. 'Inequalities in Pregnancy and Early Years and the Impact across the Life Course: Progress and Future Challenges.' Pp. 69-94 in Challenging Health Inequalities: From Acheson to 'Choosing Health', edited by Elizabeth Dower and Nick Spencer. Bristol: Policy Press.

Stuckler, David, Lawrence King and Martin McKee. 2009. 'Mass Privatisation and the Post-communist Mortality Crisis: A Cross-national Analysis.' The Lancet 373: 399-407.

United Nations. 2010. Population and Vital Statistics Report: Series A. Retrieved 9 July 2010 (http://unstats.un.org/unsd/demographic/products/vitstats/seriesa2.htm).

Večerník, Jiří. 1999. 'Inequalities in Earnings, Incomes, and Household Wealth.' Pp. 115-136 in Ten Years of Rebuilding Capitalism, edited by Jiří Večerník and Petr Matějů. Prague: Academia.

Večerník, Jiří. 2001. 'Earnings Disparities in the Czech Republic: Evidence of the Past Decade and Cross-national Comparison.' Prague Economic Papers 10: 201-222.

Večerník, Jiří and Petr Matějů (eds.). 1999. Ten Years of Rebuilding Capitalism. Czech Society 1898-1998. Prague: Academia.

Wise, Paul H. 2003. 'The Anatomy of a Disparity in Infant Mortality.' Annual Review of Public Health 24: 341-362. 


\section{Appendix A: \\ Procedures used to convert birth weight intervals to a continuous measurement}

We had access to the complete birth database for the years 1990, 1998, and 2007. We had only multi-way tables for the other years (1994, 1996, 2000, 2002, and 2004). In the multi-way tables individual births are classified by birth weight interval and by other variables (sex, parity, mother's age, mother's education, marital status, length of gestation, and district). The birth weight intervals were (1) less than 1500 grams, (2) 1500-2499 grams, (3) 2500-2999 grams, (4) 3000-3499 grams, and (5) 3500 or more grams. We converted these categories to birth weight measured in grams-i.e. a ratio variable-in the following sequence of steps:

a. We computed the mean birth weight for all births in a given birth weight interval using 1990 data. This resulted in a set of five mean values, one for each birth weight interval.

b. We obtained the means of birth weight intervals for 1998 and 2007 in a similar fashion

c. We used the linear extrapolation method to estimate the interval means for other years. We used the 1990 and 1998 mean values to estimate interval means in 1992, 1994, and 1996. Similarly, we used the 1998 and 2007 mean values to estimate interval means in 2000, 2002, and 2004.

We ended up with only five unique birth weight values in each year. This is a ratio variable, since it respects the underlying scale (weight in grams) and maintains its key interpretative advantage: the estimated effects can be interpreted as the expected change in birth weight (in grams) produced by a one unit change in an explanatory variable. 


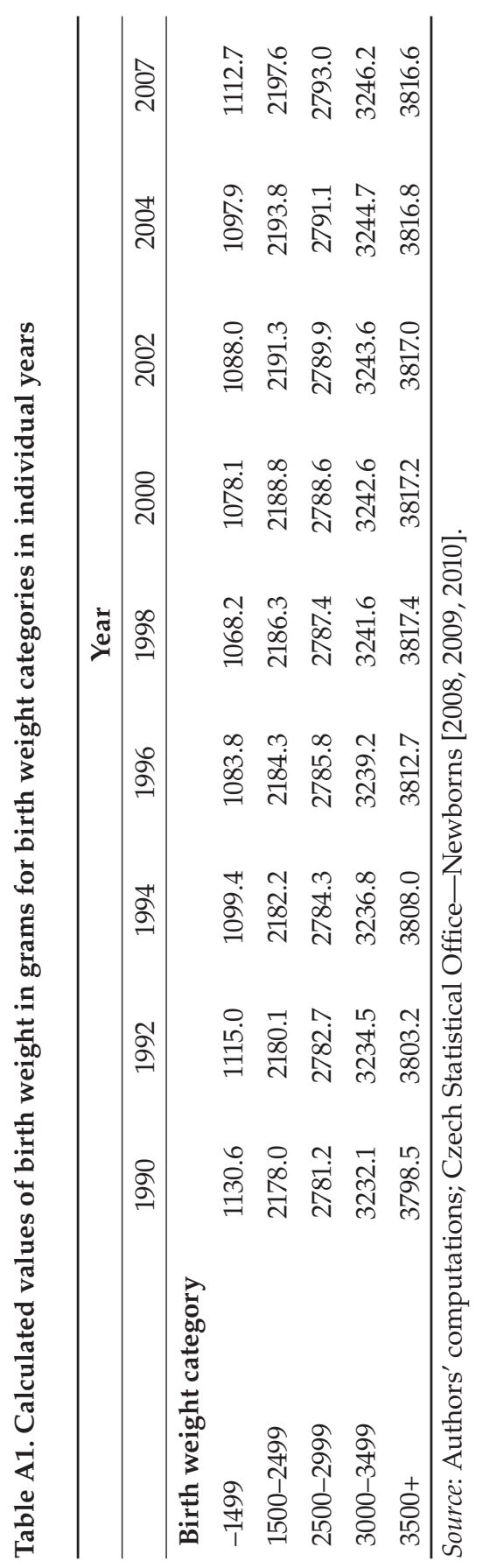




\section{Appendix B: Detailed results}

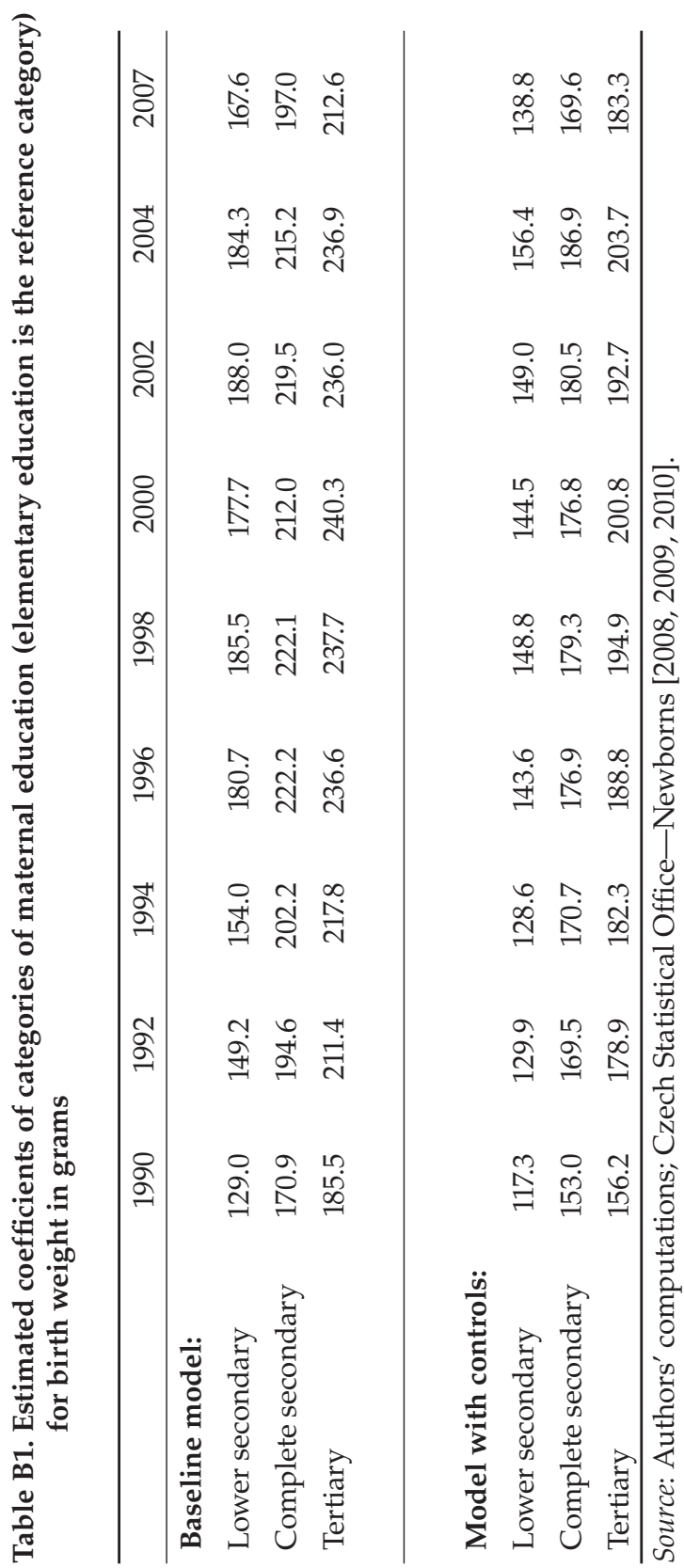




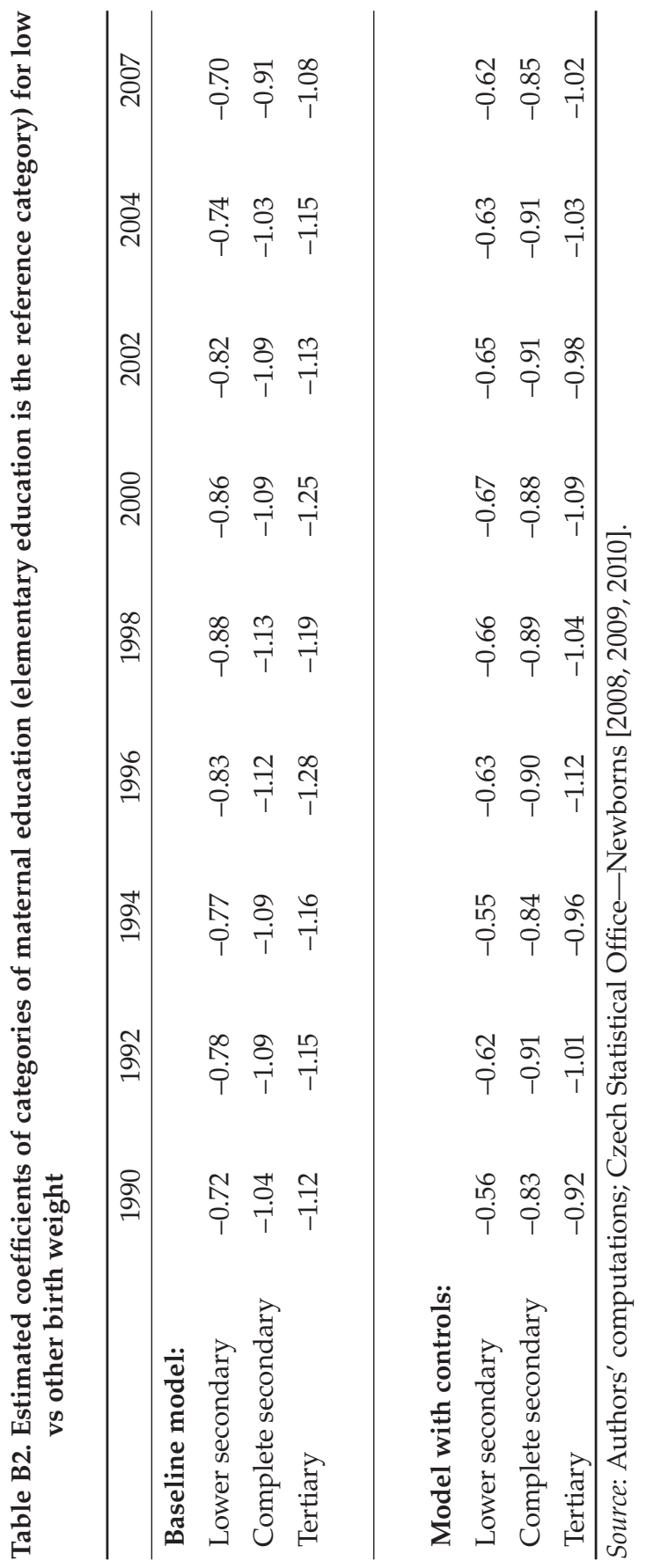




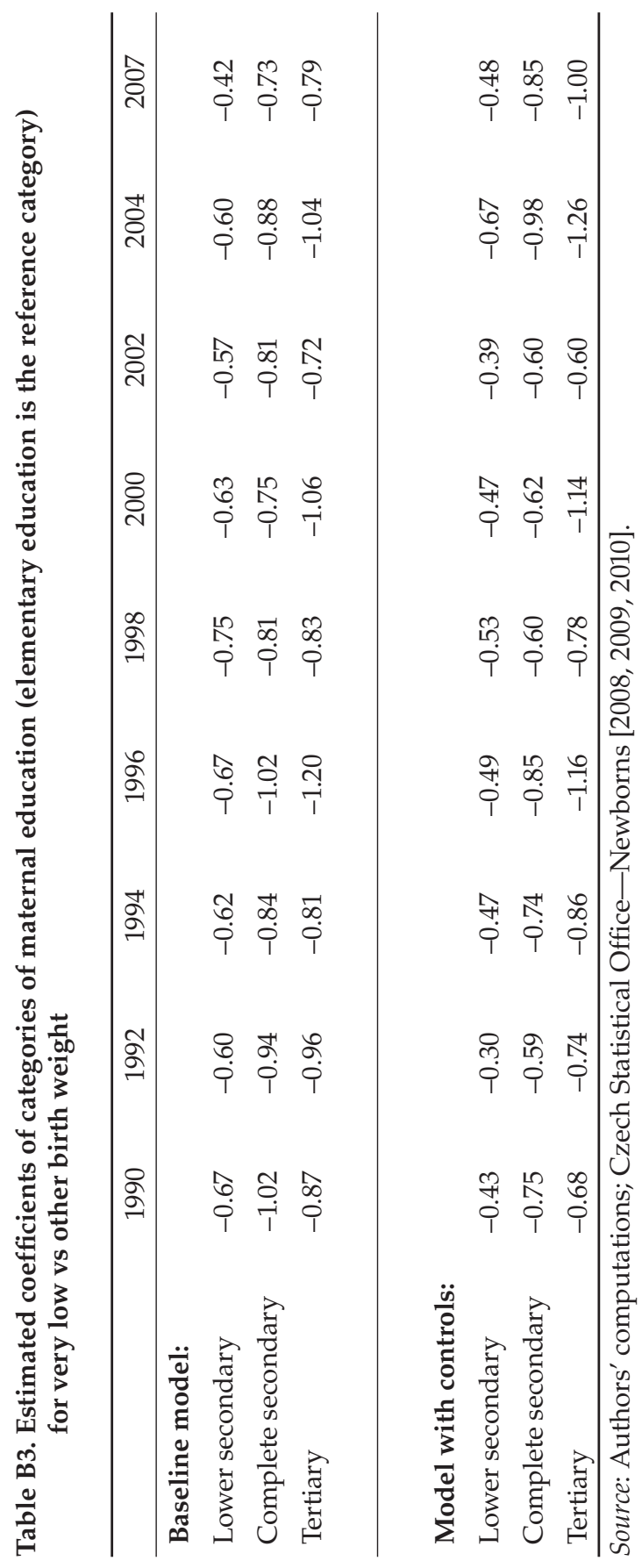




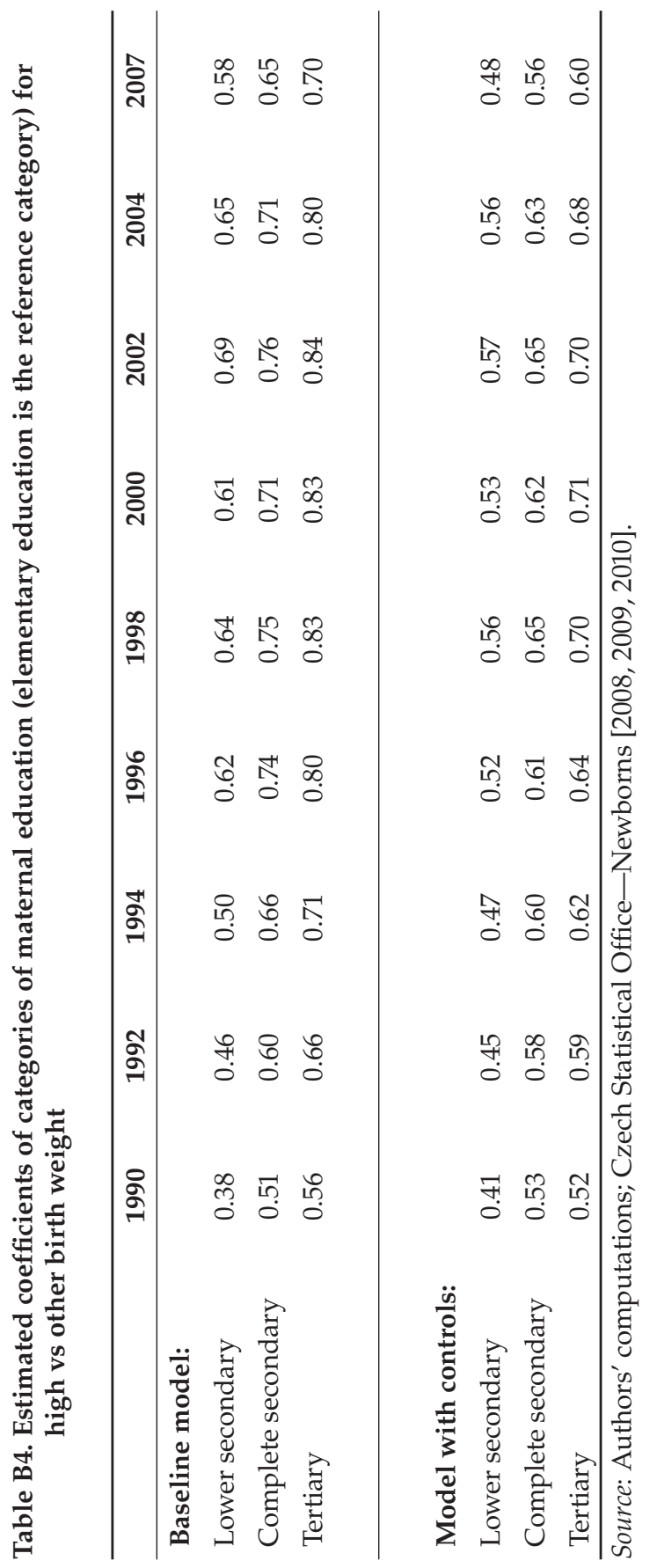




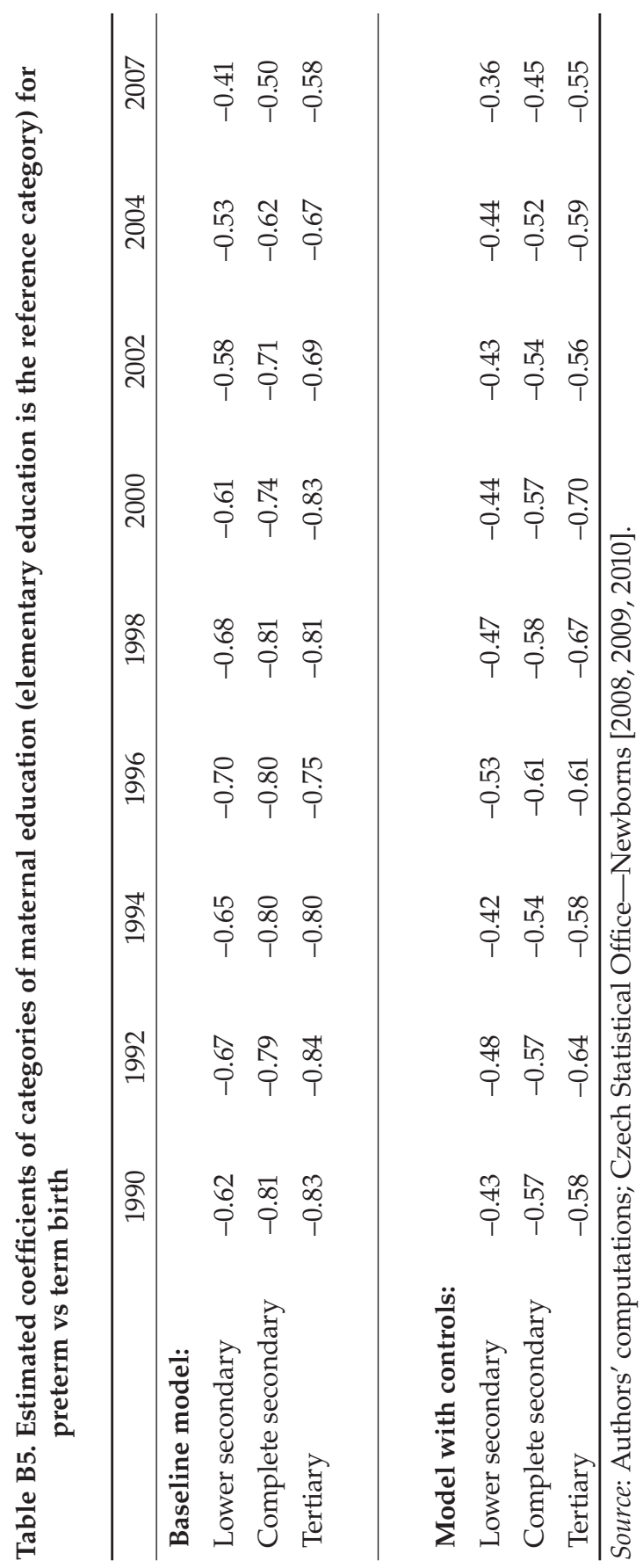




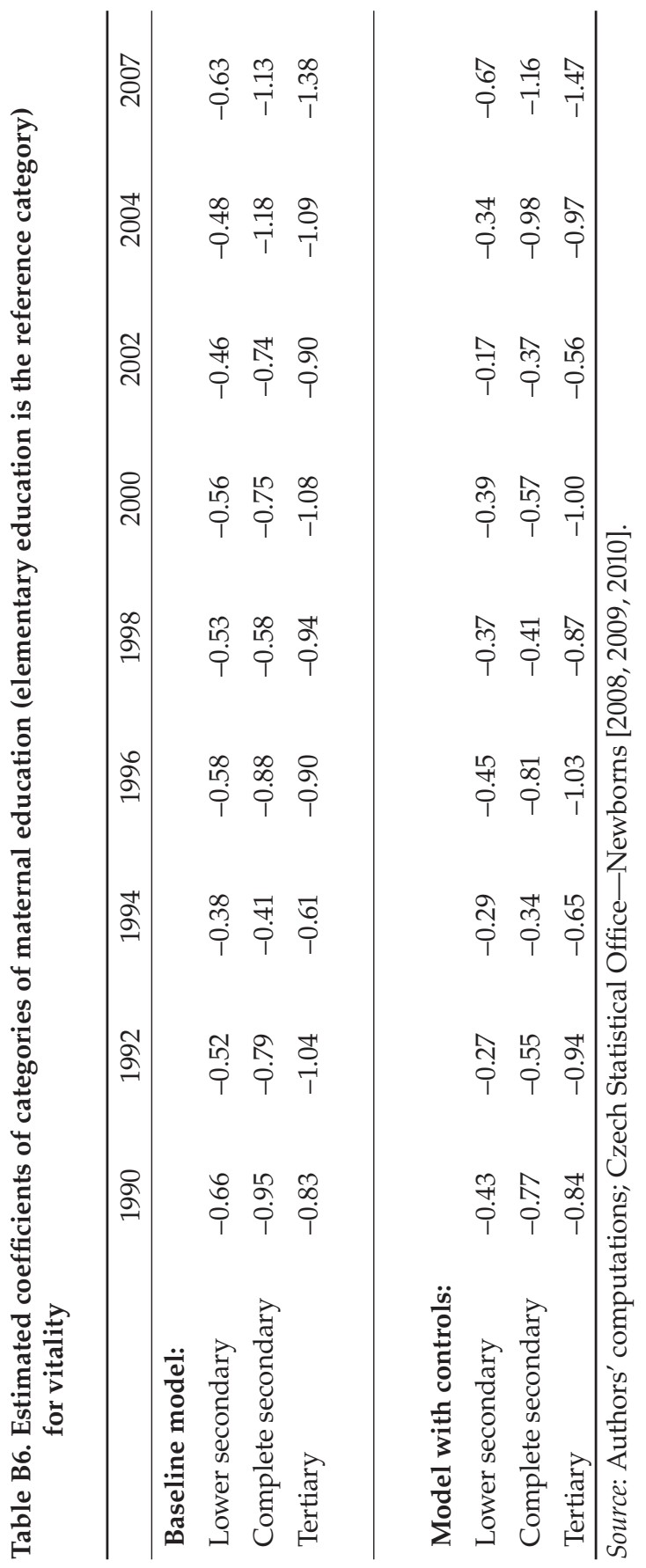

